\title{
Paraprofessional Involvement in Self-Determination Instruction for Students With High-Incidence Disabilities
}

KATHLEEN LYNNE LANE

University of North Carolina at Chapel Hill

ERIK W. CARTER

Vanderbilt University

LYNN SISCO

University of Wisconsin-Madison

ABSTRACT: Although enhancing students' self-determination is advocated as a central elenient of high-quality special education and transition services, little is known about the ways in which paraprofessionals are involved in promoting self-determination or the extent to which they share teachers' views regarding its importance. The authors surveyed 223 paraprofessionals from 115 randomly selected public schools to examine their perspectives on promoting self-determination among students with high-incidence disabilities. Overall, paraprofessionals attributed high ievels of importance to each of the 7 component elements of self-determination (i.e., choice making, clecision making, problem solving, goal setting and attainment, self-advocacy and leadership, self-management and self-regulation, and self-awareness and self-knowledge). The extent to which partprofessionals reported providing instruction addressing each of the 7 components of self-determination was moderate, with average ratings all slightly above the midpoint of the scale. This article presents implications for the involvement of paraprofessionals in supporting the development of self-determination among students with high-incidence disabilities, along with recommendations for future research.

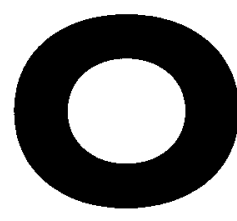

ver' the past 2 decades, selfdetermination has emerged as an important construct within the field of special education and secondary transition ser- vices. This emphasis on promoting studer.ts' selfdetermination is now evident within legislative and policy initiatives (i.e., Field \& Hoffman, 2002; Individuals With Disabilities Education Act, IDEA, 2004), state standards (Konrad, 
Walker, Fowler, Test, \& Wood, 2008; Wehmeyer, Field, Doren, Jones, \& Mason, 2004), and professional competencies (Council for Exceptional Children, 2009; National Alliance for Secondary Education and Transition, 2005). Concurrently, mounting empirical evidence suggests that selfdetermination is strongly associated with improved postschool outcomes (Test, Mazotti, et al., 2009; Wehmeyer \& Palmer, 2003), and numerous studies have demonstrated that self-determination can be effectively taught to students with high-incidence disabilities (Carter, Lane, Crnobori, Bruhn, \& Oakes, 2011; Test, Fowler, Brewer, \& Wood, 2005; Wehmeyer, Palmer, Lee, Williams-Diehm, \& Shogren, 2011).

\section{Best and recommended practices now highlight the importance of providing students with disabilities with meaningful opportunities to develop the skills, attitudes, and behaviors that can enhance their self-determination.}

As a result, best and recommended practices now highlight the importance of providing students with disabilities with meaningful opportunities to develop the skills, attitudes, and behaviors that can enhance their self-determination (Carter, Lane, Pierson, \& Glaeser, 2006; Cobb, Lehmann, Newman-Gonchar, \& Alwell, 2009; Landmark, Ju, \& Zhang, 2010). Instructionally, self-determination is often addressed at the level of the following component skills: choice making, decision making, problem solving, goal setting and attainment, self-advocacy and leadership, selfmanagement and self-regulation, and self-awareness and self-knowledge (Wehmeyer, Agran, \& Hughes, 2000; Wehmeyer \& Field, 2007). Opportunities to develop greater capacities in each of these areas can be provided formally and informally through an array of curricular materials, instructional strategies, and naturalistic approaches embedded throughout the school day (Konrad et al., 2008; Wehmeyer et al., 2004). However, relatively few studies have explored the avenues through which students with high-incidence dis- abilities are provided opportunities to develop these skills through school.

Prior descriptive studies are consistent in their findings that self-determination is a highly valued instructional domain among both special and general education teachers (Cho, Wehmeyer, \& Kingston, 2011; Mason, Field, \& Sawilowsky, 2004; Stang, Carter, Lane, \& Pierson, 2009; Wehmeyer et al., 2000; Zhang, Wehmeyer, \& Chen, 2005). For example, Carter, Lane, Pierson, and Stang (2008) found more than two thirds of high school teachers rated teaching problem solving, self-management and self-regulation, decision making, and goal setting and attainment skills as very important relative to other instructional priorities in their classroom. Moreover, some of these same studies suggest teachers regularly focus instructional efforts on this educational domain. Stang et al. reported that more than $85 \%$ of elementary and middle school teachers said they sometimes or often taught each of the seven selfdetermination component skills in their classrooms. Given the challenges many students with high-incidence disabilities experience in the area of self-determination (Carter et al., 2006; Carter, Trainor, Owens, Swedeen, \& Sun, 2010), identifying promising avenues for teaching and reinforcing self-determined behavior remains an important endeavor.

Although general and special educators hold primary responsibility for making instructional decisions, paraprofessionals are playing an increasingly prominent role in reinforcing and augmenting these teachers' efforts within the classroom (Study of Personnel Needs in Special Education, 2002; U.S. Department of Education, 2004). Data from the 2007-2008 school year indicated that 455,820 special education paraprofessionals worked in public and charter schools in the United States (Keigher \& Gruber, 2009). Indeed, in many states, the ratio of paraprofessional fulltime equivalents (FTEs) to special educator FTE exceeds 1.0 (Giangreco, Hurley, \& Suter, 2009). Although actual practices sometimes diverge from articulated policies (Carter, O'Rourke, Sisco, \& Pelsue, 2009; Fisher \& Pleasants, in press; Giangreco, 2010; Giangreco \& Broer, 2005), appropriate roles for paraprofessionals can include providing one-to-one tutoring (if such tutoring is scheduled at a time when a student would not 
otherwise receive instruction from a teacher), assisting with classroom management, and providing instructional support services under the direct supervision of a highly qualified teacher (No Child Left Behind Act of 2001, Title 1, Section $1119[\mathrm{~g}][2])$. Despite the fact that paraprofessionals-when appropriately trained and supervised-can assist in the provision of special education and related services, little empirical research has addressed the roles these staff play in fostering self-determination among the students with whom they work.

In this study, we sought to determine whether paraprofessionals also affirmed the importance of promoting self-determination among the students with whom they worked, as well to gauge the extent to which these staff are involved in providing instructional support addressing each of seven self-determination skills. Although highly qualified teachers should set instructional

\section{Although bighly qualified teachers should set instructional priorities for students, the degree to which paraprofessionals also hold similar views regarding the importance of these [self-determination] domains could impact whether and how opportunities are provided for students to learn and practice these skills throughout the school day.}

priorities for students, the degree to which paraprofessionals also hold similar views regarding the importance of these educational domains could impact whether and how opportunities are provided for students to learn and practice these skills throughout the school day. The few articles addressing this issue have cautioned that paraprofessionals may inadvertently hinder, rather than enhance, student self-determination (Giangreco, Yuan, McKenzie, Cameron, \& Fialka, 2005; Minondo, Meyer, \& Xin, 2001). Thus, it would be instructive to ascertain how paraprofessionals themselves view the importance of fostering such skills. Similarly, given growing concerns regarding the proper roles of paraprofessionals in the education of students with disabilities, it is important to determine the extent to which these staff are actu- ally involved in providing instruction related to this educational domain. At present, the extent to which paraprofessionals play a role in addressing student self-determination is unclear. Finally, the views of paraprofessionals are likely influenced by multiple factors, including their prior training, education, experience, and familiarity with the broader self-determination construct. An understanding of these factors could inform efforts to strengthen the quality of the training, direction, and supervision of paraprofessionals working with students with disabilities.

\section{PURPOSE}

The purpose of this study was to examine paraprofessionals' perspectives on promoting selfdetermined behavior for students with highincidence disabilities. We examined four research questions:

- How do paraprofessionals view the importance of providing instruction in each of seven self-determination skill domains relative to other priorities?

- To what degree do paraprofessionals report spending time teaching each skill?

- What is the relationship between the importance and actual instructional time dievoted to each domain?

- What paraprofessional characteristics (e.g., gender, years of experience, educational attainment, familiarity with the construct, access to professional development activities) predict ratings of self-determination?

\section{ETHOD}

\section{PARTICIPANTS}

Participants in this survey study were $22 \%$ paraprofessionals from 115 randomly selected public schools. Consistent with national patterns, the majority of paraprofessionals were female and had not obtained a college degree (see Table 1). Participants averaged 10.10 years (SD := 6.70 years) experience working as a paraprofessional. When asked about the settings in whic.s they 


\begin{tabular}{|c|c|c|c|c|c|c|}
\hline \multirow[b]{2}{*}{ Variable } & \multicolumn{2}{|c|}{$\begin{array}{c}\text { Elementary } \\
\mathrm{n}=112\end{array}$} & \multicolumn{2}{|c|}{$\begin{array}{c}\text { Secondary } \\
\mathrm{n}=109\end{array}$} & \multicolumn{2}{|c|}{$\begin{array}{l}\text { Combined } \\
\mathrm{N}=223\end{array}$} \\
\hline & $\mathrm{n}$ & $\%$ & $\mathrm{n}$ & $\%$ & $\mathrm{n}$ & $\%$ \\
\hline \multicolumn{7}{|l|}{ Gender } \\
\hline Female & 109 & 97.32 & 101 & 92.66 & 212 & 95.07 \\
\hline Male & 3 & 2.68 & 8 & 7.34 & 11 & 4.93 \\
\hline \multicolumn{7}{|l|}{ Years as a paraprofessional } \\
\hline $0-5$ & 33 & 31.73 & 21 & 20.59 & 55 & 26.57 \\
\hline $6-10$ & 34 & 32.69 & 36 & 35.29 & 70 & 33.82 \\
\hline $11-15$ & 17 & 16.35 & 21 & 20.59 & 38 & 18.36 \\
\hline $16-35$ & 20 & 19.23 & 24 & 23.53 & 44 & 21.26 \\
\hline \multicolumn{7}{|l|}{ Highest degree } \\
\hline High school & 23 & 20.54 & 28 & 25.93 & 51 & 22.97 \\
\hline Some college (no degree) & 35 & 31.25 & 29 & 26.85 & 66 & 29.73 \\
\hline Associate’s degree & 23 & 20.54 & 16 & 14.81 & 39 & 17.57 \\
\hline Bachelor's degree & 25 & 22.32 & 31 & 28.70 & 56 & 25.23 \\
\hline Master's degree & 3 & 2.68 & 2 & 1.85 & 5 & 2.25 \\
\hline Other & 3 & 2.68 & 2 & 1.85 & 5 & 2.25 \\
\hline \multicolumn{7}{|l|}{ Disability categories served } \\
\hline Learning disability & 85 & 75.89 & 99 & 90.83 & 186 & 83.41 \\
\hline Autism & 76 & 67.86 & 76 & 69.72 & 154 & 69.06 \\
\hline Emotional disturbance & 65 & 58.04 & 80 & 73.39 & 147 & 65.92 \\
\hline Intellectual disabilities & 56 & 50.00 & 65 & 59.63 & 122 & 54.71 \\
\hline Speech/language impairment & 56 & 50.00 & 58 & 53.21 & 114 & 51.12 \\
\hline Multiple disabilities & 28 & 25.00 & 34 & 31.19 & 62 & 27.80 \\
\hline Other health impairment & 27 & 24.11 & 23 & 21.10 & 50 & 22.42 \\
\hline Visual impairment & 10 & 8.93 & 20 & 18.35 & 32 & 14.35 \\
\hline Orthopedic impairment & 8 & 7.14 & 14 & 12.84 & 22 & 9.87 \\
\hline Hearing impairment & 7 & 6.25 & 10 & 9.17 & 17 & 7.62 \\
\hline Traumatic brain injury & 3 & 2.68 & 13 & 11.93 & 16 & 7.17 \\
\hline Deaf-blindness & 6 & 5.36 & 4 & 3.67 & 10 & 4.48 \\
\hline \multicolumn{7}{|l|}{ Primary work setrings } \\
\hline Both general and special ed. & 39 & 34.82 & 48 & 44.86 & 87 & 39.37 \\
\hline Mostly general education & 41 & 36.61 & 36 & 33.64 & 78 & 35.29 \\
\hline Mostly special education & 26 & 23.21 & 17 & 15.89 & 43 & 19.46 \\
\hline Other & 4 & 3.57 & 4 & 3.74 & 9 & 4.07 \\
\hline Multiple settings indicated & 2 & 1.79 & 2 & 1.87 & 4 & 1.81 \\
\hline
\end{tabular}

Note. Two respondents did not specify school level status. Percentages are based on the number of participants who completed the given item.

abecause multiple categories could be selected, percentages add up to more than $100 \%$.

primarily worked with students with disabilities, the largest number of paraprofessionals indicated they supported students in both general and special education classrooms (39\%) or mostly general education classrooms (35\%). Although all of the participants in this study described the majority of the students with whom they worked most closely as having mild or high-incidence disabilities (see Survey Instrument), these paraprofessionals reported working with students 
served under multiple special education categories (see Table 1).

According to administrative rules in the state in which this study was conducted, paraprofessionals (i.e., aides) are defined as:

a school employee who works under the direct supervision of a licensed teacher in a school or district whose responsibilities include, but are not limited to, supporting the lesson plan of the licensed teacher, providing technical assistance to the teacher, helping with classroom control or management, and other duties as assigned. Aides may not serve as substitute teachers. (Wisconsin Administrative Code PI 34.01[4]; Wisconsin Department of Public Instruction, 2010, 91)

\section{SETTINGS}

Paraprofessionals worked with students with disabilities at 68 elementary, 27 middle, and 20 high schools from 27 school districts in Wisconsin. School level was self-reported by paraprofessionals as either elementary, middle, or high school and was collapsed into elementary or secondary (i.e., middle and high school) levels for analytic purposes. Average student enrollment in participating districts was 2,994 students $(S D=499$; range, 210-24,670 students). School enrollment across participating schools averaged 520 students $(S D=$ 98; range, 92-2,061 students). Average ethnicity across schools was $79.2 \%$ European American $(S D=18.7 \%$; range, $10.9 \%-99.1 \%), 7.3 \%$ African American $(S D=10.6 \%$; range, $0 \%-50.4 \%)$, $7.0 \%$ Hispanic $(S D=6.5 \%$; range, $0.0 \%$ $32.2 \%), 5.9 \%$ Asian American ( $S D=6.4 \%$; range, $0.0 \%-33.3 \%$ ) and $0.7 \%$ other ethnicities $(S D=0.6$; range, $0 \%-2.8 \%)$. The average percentage of students eligible to receive free or reduced-price meals across these schools was $29.0 \%(S D=17.5 \%$; range, $0.6 \%-83.4 \%)$.

\section{SURVEY INSTRUMENT}

We asked paraprofessionals to complete a twopage, printed survey consisting of two sections and 23 questions. In the first section, we asked paraprofessionals to provide ratings of seven instructional domains associated with self-determination for the "students with disabilities with whom you work most closely during. a typical school day." These domains were: choice making, decision making, problem solving, goal setting and attainment, self-advocacy and leadership, selfmanagement and self-regulation, and self-iwareness and self-knowledge First, paraprofessionals rated the importance of each instructional domain using a 6 -point, Likert-type scale ( $1=$ low, 6 = high). Specifically, the survey asked: "How important do you think teaching this skill is compared with other instructional priorities for your students with disabilities?" Second, paraprofessionals rated how often they taught each skill to students with disabilities, using a 6-point, l'ikerttype scale $(1=$ never, $6=$ often $)$. Brief examples of instructional activities accompanied each instructional domain. For example, "teaching students to monitor and evaluate their own behavior, select and provide their own reinforcement, se: their own schedule, and to self-direct learning through strategies like self-instruction" was listed adjacent to self-management and self-regulation skills and "teaching students to know and stand up for their rights, to communicate effectively and assertively, and to be an effective leader or team member" was listed next to self-advocacy and leadership skills. These items were adapted from Wehmeyer and colleagues (2000) by making minor wording changes to the item instructions and adding a second response dimension (i.e., frequency of skill instruction). However, consistent with the original survey, our survey did not provide operational definitions for each anchor. Nonetheless, the instrument used in this study had strong internal consistency with coefficient alpha reliabilities of .83 and .87 for the importance and actual instruction scales, respectively. The same tool has been used reliably in previous studies involving more than 1,200 general and special educators and is available by request from the authors (Carter et al., 2008; Stang et al., 2009). Wehmeyer: et al. drew upon a functional model of self-determinarion (e.g., Wehmeyer, 1999) when crearing their survey and included component skills of selfdetermination that could be addressed through instructional efforts.

In the second section, we asked paraprofessionals to provide (a) basic demographic information, including years of experience, gendier, and highest level of education; (b) information about their current job position, including school level 
(i.e., elementary, middle, high) and primary classroom settings (i.e., mostly general education classrooms, mostly special education classrooms [e.g., resource, self-contained, life skills], both general and special education classrooms equally, other); and (c) a description of the categories of students with disabilities with whom they worked and their own determination of the level of disability experienced by most of the students with whom they worked most closely (i.e., mild disabilities [also called high-incidence disabilities] or moderate to severe disabilities [also called low-incidence disabilities]). We also asked paraprofessionals about (a) their familiarity with the concept of self-determination for students with disabilities using a 3-point Likert-type scale (i.e., not at all familiar, somewhat familiar, very familiar), and (b) the extent to which self-determination strategies are addressed during inservice or other professional development opportunities in their school or district using a 3-point Likert-type scale (i.e., never, sometimes, frequently). In this article, we focus only on findings from paraprofessionals reporting that they worked with students with high-incidence disabilities. Findings from paraprofessionals working with students with low-incidence disabilities are described in Carter, Lane, and Sisco (2011). We estimated the approximate completion time for the questionnaire as less than $15 \mathrm{~min}$.

\section{PROCEDURES}

After securing Institutional Review Board approval, we used proportional stratified random sampling to select 40 school districts from among all school districts $(N=151)$ in three different regional service areas in Wisconsin. We selected these service areas because they included school districts serving rural, suburban, and urban communities. We compiled a list of all school districts in the region using a list obtained from the state's Department of Public Instruction. We eliminated special schools (e.g., alternative schools, juvenile detention centers; and transition schools), preschools, and virtual schools from this list.

We created three different sampling frames to capture small-, medium-, and large-sized districts. For purposes of this study, we defined small-sized districts $(N=68)$ as having enroll- ment sizes less than 1,000 students, medium-sized districts $(N=71)$ as having enrollment sizes between 1,000 and 5,000 students, and large-sized districts $(N=12)$ as having enrollment sizes greater than 5,000 students. We randomly samplèd 18 small-sized school districts, 18 mediumsized school districts, and four large-sized school districts. Of these 40 school districts, 10 declined our invitation to participate and six school districts did not respond. In three of the remaining 24 school districts, we did not receive any response from building-level administrators and thus no data were collected. Of the 21 school districts where paraprofessionals completed the survey, two were exclusively elementary school districts (i.e., Grades K-8) and two were exclusively high school districts (i.e., Grades 9-12). The two high school districts, one of the elementary school districts, and another small-sized school district were part of larger consortiums in which administrators wanted to invite all other consortium districts to participate in the study. This resulted in a total of 32 school districts participating in our study: 90 elementary schools, 39 middle schools, and 31 high schools. For this particular article-focused only on paraprofessionals working with students with high-incidence disabilities-paraprofessionals were employed at 68 elementary schools, 27 middle schools, and 20 high schools. (Findings for paraprofessionals working with students with severe disabilities are reported in Carter et al., 2011.)

We sent each school district's special education administrator an invitation to participate, following up by phone and/or e-mail as needed to review the project, answer questions, and request that permission forms be returned for interested districts. When permission was granted at the district level, we followed a similar process with building-level administrators at each school. Eleven school districts opted to have the survey distribution and collection handled at the district level to minimize the burden on building-level administrators; however, permission was still sought at the building level prior to distributing surveys to paraprofessionals. If the building-level administrator granted us permission to distribute the survey to paraprofessionals in their school, we collaboratively developed a distribution process that would be most effective and convenient for 
the school. We prepared and sent survey materials to the study liaison at each school, providing stepby-step instructions for distributing surveys to paraprofessionals and returning completed surveys to us. Surveys were distributed in various ways, including campus mailboxes, school/district staff inservice or professional development meetings, weekly school staff: meetings, or in person. Paraprofessionals completed surveys individually and anonymously. Oprions for completed survey return included directly mailing the survey back to us in a prepaid envelope or returning it to the school's point of contact. Respondents were encouraged to contact us-rather than the school liaison-with questions regarding the survey; a few respondents made such inquiries. The estimated overall participation rate for paraprofessionals across schools averaged $86.0 \%$ (range, $0 \%-100 \%)$.

\section{STUDY DESIGN AND DATA \\ ANALYSIS PLAN}

This study involved descriptive analyses of the self-reported ratings of paraprofessionals who were working primarily with students with highincidence disabilities. To determine how paraprofessionals evaluate the importance of each skill, we used descriptive statistics to summarize ratings of importance across respondents. Due to small cell sizes for some item-level ratings, the 6-point, Likert-type scale was collapsed into three categories: low (ratings of 1 or 2), medium (ratings of 3 or 4), and high (ratings of 5 or 6 ) prior to data analysis. After restructuring the data set to create seven variables per participant, we conducted a one-way analysis of variance (ANOVA) across the seven items measuring the importance of self-determined behaviors. A significant ANOVA was followed by a Tukey multiple comparison ( $\alpha=$ .05 ) to determine differences in the importance ratings across the items. (The Tukey comparison technique was selected due to the imbalanced cell sizes.) Table 2 reports descriptive statistics of these three categories (frequency counts, percentages of ratings, means, and standard deviations) as well as means and standard deviations for the overall clusters. The same descriptive statistics and significance tèsting procedures described for the first research question were used to analyze ratings of how often paraprofessionals teach each of the seven self-determination skills.

Next, we computed Pearson correlation coefficients to examine the relation between paraprofessionals' ratings of the importance and frequency of instruction for each of the seven selfdetermination domains. Finally, we conducted two stepwise regressions to identify the extent to which paraprofessional characteristics predicted (a) the importance paraprofessionals placed on self-determination skills and (b) the frequency with which these skills are taught. These characteristics included: school level taught (elementary versus middle/high school grade levels), work setting (general, special education, or both settings), gender, years of experience, educational artainment, familiarity with the construct, and prior access to professional development activities. A jackknife procedure detected outliers (Kleinbaum, Kupper, Muller, \& Nizam, 1998). The residual sums of squares, the multiple correlation coefficient, and $\mathrm{Cp}$ criterion values were examined to determine the most parsimonious set of piedictors to retain in the model (Borthwick-[luffy, Lane, \& Widaman, 1997). Further, we examined studentized residuals, leverage, and Cook's $D$ values to evaluate the validity of the regression models (Kleinbaum et al., 1998). None of these statistical procedures yielded extreme values thereby suggesting that outliers were not present and, as a result, the regression results were considered accurate. Two students entered all data: with fidelity of data entry assessed for $100 \%$ of the surveys. Any data entry errors were corrected.

\section{RES U LT S}

\section{HOW DO PARAPROFESSIONALS}

EVALUATE THE IMPORTANCE OF PROVIDING INSTRUCTION?

Overall, paraprofessionals attributed high (i.e., ratings of 5 or 6 ) levels of importance to each of the seven component elements of self-determination (see Table 2), with mean scores ranging from $4.98(S D=1.15)$ for goal setting and attairment to $5.45(S D=0.80)$ for problem-solving skills. More than $80 \%$ of paraprofessionals rated choice 


\begin{tabular}{|c|c|c|c|c|c|c|c|c|}
\hline \multirow[b]{2}{*}{ Domain } & \multicolumn{4}{|c|}{$\begin{array}{l}\text { Importance } \\
\%(\mathrm{n})\end{array}$} & \multicolumn{4}{|c|}{$\begin{array}{c}\text { Instruction } \\
\%(\mathrm{n}) \\
\end{array}$} \\
\hline & $\begin{array}{l}\text { I or } 2 \\
\text { (Low) }\end{array}$ & $\begin{array}{c}3 \text { or } 4 \\
\text { (Medium) }\end{array}$ & $\begin{array}{l}5 \text { or } 6 \\
(\text { High }) \\
\end{array}$ & $\begin{array}{c}\mathrm{M} \\
(\mathrm{SD}) \\
\end{array}$ & $\begin{array}{c}1 \text { or } 2 \\
\text { (Never) }\end{array}$ & $\begin{array}{c}3 \text { or } 4 \\
\text { (Sometimes) }\end{array}$ & $\begin{array}{l}5 \text { or } 6 \\
\text { (Often) }\end{array}$ & $\begin{array}{c}M \\
(\mathrm{SD})\end{array}$ \\
\hline Choice making & $\begin{array}{l}0.90 \\
(2)\end{array}$ & $\begin{array}{l}18.47 \\
(41)\end{array}$ & $\begin{array}{l}80.63 \\
(179)\end{array}$ & $\begin{array}{c}5.18 \\
(0.93)\end{array}$ & $\begin{array}{l}5.02 \\
(11)\end{array}$ & $\begin{array}{c}40.18 \\
(88)\end{array}$ & $\begin{array}{l}54.79 \\
(i 20)\end{array}$ & $\begin{array}{c}4.52 \\
(1.29)\end{array}$ \\
\hline Decision making & $\begin{array}{l}2.76 \\
(6)\end{array}$ & $\begin{array}{c}15.21 \\
(33)\end{array}$ & $\begin{array}{l}82.03 \\
(178)\end{array}$ & $\begin{array}{c}5.17 \\
(1.08)\end{array}$ & $\begin{array}{r}17.05 \\
(37)\end{array}$ & $\begin{array}{c}36.87 \\
(80)\end{array}$ & $\begin{array}{l}46.08 \\
(100)\end{array}$ & $\begin{array}{c}4.11 \\
(1.49)\end{array}$ \\
\hline Problem solving & $\begin{array}{l}0.45 \\
(1)\end{array}$ & $\begin{array}{l}11.36 \\
(25)\end{array}$ & $\begin{array}{l}88.18 \\
(194)\end{array}$ & $\begin{array}{l}5.45 \\
(0.80)\end{array}$ & $\begin{array}{l}4.59 \\
(10)\end{array}$ & $\begin{array}{c}29.82 \\
(65)\end{array}$ & $\begin{array}{l}65.60 \\
(143)\end{array}$ & $\begin{array}{c}4.77 \\
(1.18)\end{array}$ \\
\hline $\begin{array}{l}\text { Goal setting and } \\
\text { attainment }\end{array}$ & $\begin{array}{l}5.00 \\
(11)\end{array}$ & $\begin{array}{c}20.91 \\
(46)\end{array}$ & $\begin{array}{l}74.09 \\
(163)\end{array}$ & $\begin{array}{c}4.98 \\
(1.15)\end{array}$ & $\begin{array}{r}23.18 \\
(51)\end{array}$ & $\begin{array}{c}42.73 \\
(94)\end{array}$ & $\begin{array}{l}34.09 \\
(75)\end{array}$ & $\begin{array}{l}3.75 \\
(1.47)\end{array}$ \\
\hline $\begin{array}{l}\text { Self-advocacy } \\
\text { and leadership }\end{array}$ & $\begin{array}{l}2.25 \\
(5)\end{array}$ & $\begin{array}{c}20.27 \\
(45)\end{array}$ & $\begin{array}{l}77.48 \\
(172)\end{array}$ & $\begin{array}{c}5.14 \\
(1.08)\end{array}$ & $\begin{array}{r}15.77 \\
(35)\end{array}$ & $\begin{array}{c}38.29 \\
(85)\end{array}$ & $\begin{array}{l}45.95 \\
(102)\end{array}$ & $\begin{array}{c}4.16 \\
(1.46)\end{array}$ \\
\hline $\begin{array}{l}\text { Self-management } \\
\text { and self-regulation }\end{array}$ & $\begin{array}{l}4.05 \\
(9)\end{array}$ & $\begin{array}{c}21.62 \\
(48)\end{array}$ & $\begin{array}{r}74.32 \\
(165)\end{array}$ & $\begin{array}{l}5.04 \\
(1.14)\end{array}$ & $\begin{array}{r}16.22 \\
(36)\end{array}$ & $\begin{array}{c}36.94 \\
(82)\end{array}$ & $\begin{array}{l}46.85 \\
(104)\end{array}$ & $\begin{array}{c}4.18 \\
(1.47)\end{array}$ \\
\hline $\begin{array}{l}\text { Self-awareness } \\
\text { and self-knowledge }\end{array}$ & $\begin{array}{l}1.80 \\
(4)\end{array}$ & $\begin{array}{c}18.02 \\
(40)\end{array}$ & $\begin{array}{l}80.18 \\
(178)\end{array}$ & $\begin{array}{l}5.15 \\
(0.94)\end{array}$ & $\begin{array}{r}12.61 \\
(28)\end{array}$ & $\begin{array}{c}39.64 \\
(88)\end{array}$ & $\begin{array}{l}47.75 \\
(106)\end{array}$ & $\begin{array}{c}4.23 \\
(1.41)\end{array}$ \\
\hline Overall Cluster & & & & $\begin{array}{l}36.10 \\
(5.02)\end{array}$ & & & & $\begin{array}{l}29.60 \\
(7.40)\end{array}$ \\
\hline
\end{tabular}

Note. Percentages are based on the number of participants who completed the given item.

making, decision making, problem solving, and self-awareness and self-knowledge as having high importance relative to other instructional priorities for the students with whom they worked most closely. More than $70 \%$ of paraprofessionals also rated goal setring and attainment, self-advocacy and leadership skills, and self-management and self-regulation skills as having high importance. Table 3 displays findings by elementary and secondary levels.

Results of the ANOVA comparing the seven domains indicated statistically significant differences between items, $F(6,1540)=4.56, p<$ $.0001, R^{2}=1.75 \%$. According to post-hoc Tukey multiple comparison procedures, problem solving, choice making, and decision making were rated significantly higher in terms of importance relative to the other domains, with no significant differences between these three mean ratings. Further, there were no significant differences between the remaining four domains.
TO WHAT EXTENT DO

PARAPROFESSIONALS REPORT

TEACHING EACH SKILL?

Paraprofessionals reported that they sometimes to often taught each of the seven skills associated with enhanced self-determination, with mean scores ranging from $3.75(S D=1.47)$ for goal setting and attainment to $4.77(S D=1.18)$ for problem-solving skills (see Table 2). However, choice making and problem solving were the only two skills that more than half of paraprofessionals reported often teaching (i.e., ratings of 5 or 6 ) to the students with whom they worked.

Results of the ANOVA comparing the seven domains indicated statistically significant differences between items with respect to instructional frequency, $F(6,1536)=11.64, p<.0001, R^{2}=$ $4.35 \%$. According to post-hoc Tukey multiple comparison procedures, problem solving and choice making were rated significantly higher in terms of instructional frequency relative to the 
Ratings of Skill Importance and Reported Instruction by School Level

\begin{tabular}{|c|c|c|c|c|c|c|c|c|}
\hline \multirow[b]{2}{*}{$\begin{array}{l}\text { Self-determination } \\
\text { element }\end{array}$} & \multicolumn{3}{|c|}{ Importance (\% ranking) } & \multirow[b]{2}{*}{$\mathrm{M}(\mathrm{SD})$} & \multicolumn{3}{|c|}{ Instruction (\% ranking) } & \multirow[b]{2}{*}{$M(S D)$} \\
\hline & $\begin{array}{l}1 \text { or } 2 \\
\text { (Low) }\end{array}$ & $\begin{array}{c}3 \text { or } 4 \\
\text { (Medium) } \\
\end{array}$ & $\begin{array}{l}5 \text { or } 6 \\
\text { (High) }\end{array}$ & & $\begin{array}{c}1 \text { or } 2 \\
(\text { Never }) \\
\end{array}$ & $\begin{array}{c}3 \text { or } 4 \\
\text { (Sometimes) } \\
\end{array}$ & $\begin{array}{l}5 \text { or } 6 \\
\text { (Often) }\end{array}$ & \\
\hline \multicolumn{9}{|l|}{ Choice making } \\
\hline Elementary & 0.00 & 18.75 & 81.25 & $5.18(0.86)$ & 2.75 & 35.78 & 61.47 & $4.69(1.21)$ \\
\hline Secondary & 1.85 & 18.52 & 79.63 & $5.18(1.00)$ & 7.41 & 45.37 & 47.22 & $4.31(1.33)$ \\
\hline \multicolumn{9}{|l|}{ Decision making } \\
\hline Elementary & 4.59 & 21.10 & 74.31 & $4.99(1.20)$ & 19.27 & 40.37 & 40.37 & $3.94(1.48)$ \\
\hline Secondary & 0.94 & 9.43 & 89.62 & $5.34(0.91)$ & 14.15 & 33.96 & 51.89 & $4.29(1.48)$ \\
\hline \multicolumn{9}{|l|}{ Problem solving } \\
\hline Elementary & 0.00 & 9.82 & 90.18 & $5.52(0.70)$ & 0.90 & 29.73 & 69.37 & $4.92(1.01)$ \\
\hline Secondary & 0.94 & 13.21 & 85.85 & $5.36(0.90)$ & 7.62 & 30.48 & 61.90 & $4.63(1.30)$ \\
\hline \multicolumn{9}{|l|}{$\begin{array}{l}\text { Goal setting and } \\
\text { attainment }\end{array}$} \\
\hline Elementary & 6.36 & 23.64 & 70.00 & $4.88(1.19)$ & 21.82 & 46.36 & 31.82 & $3.70(1.39)$ \\
\hline Secondary & 3.70 & 17.59 & 78.70 & $5.07(1.12)$ & 24.07 & 38.89 & 37.04 & $3.82(1.55)$ \\
\hline \multicolumn{9}{|l|}{$\begin{array}{l}\text { Self-advocacy and } \\
\text { leadership }\end{array}$} \\
\hline Elementary & 0.89 & 24.11 & 75.00 & $5.14(1.06)$ & 13.39 & 42.86 & 43.75 & $4.12(1.40)$ \\
\hline Secondary & 3.70 & 16.67 & 79.63 & $5.11(1.11)$ & 18.52 & 34.26 & 47.22 & $4.18(1.53)$ \\
\hline \multicolumn{9}{|l|}{$\begin{array}{l}\text { Self-management } \\
\text { and self-regulation }\end{array}$} \\
\hline Elementary & 5.36 & 20.54 & 74.11 & $5.04(1.25)$ & 15.18 & 36.61 & 48.21 & $4.17(1.49)$ \\
\hline Secondary & 2.78 & 23.15 & 74.07 & $5.04(1.03)$ & 17.59 & 37.96 & 44.44 & $4.16(1.45)$ \\
\hline \multicolumn{9}{|l|}{$\begin{array}{l}\text { Self-awareness and } \\
\text { self-knowledge }\end{array}$} \\
\hline Elementary & 2.68 & 17.86 & 79.46 & $5.13(0.99)$ & 9.82 & 44.64 & 45.54 & $4.21(1.31)$ \\
\hline Secondary & 0.93 & 18.52 & 80.56 & $5.17(0.90)$ & 15.74 & 34.26 & 50.00 & $4.23(1.51)$ \\
\hline
\end{tabular}

Note. Percentages are based on the number of participants who completed the given item. Elementary and secondary refer to the school level in which paraprofessionals worked; combined refers to all paraprofessionals in the study.

other domains, with no significant differences between these two mean values. There were no significant differences in the ratings of instructional frequency for the other domains, with the exception of goal setting and attainment, which was taught less frequently than decision-making skills.

WHAT IS THE RELATION BETWEEN

RATINGS OF IMPORTANCE AND

SKILL INSTRUCTION?

Significant positive correlations were found for all seven items: choice-making $(r=.53, p<.001)$, decision making $(r=.47, p<.0001)$, problem solving $(r=.56, p<.0001)$, goal setting and attainment ( $r=.47, p<.0001$ ), self-advocacy and leadership skills $(r=.51, p<.0001)$, self-management and self-regulation skills $(r=.55, p<$ $.0001)$, and self-awareness and self-knorvledge $(r=.49, p<.0001)$. Correlation coefficients suggest medium relations between ratings of importance and frequency of instruction.

\section{TO WHAT EXTENT DO \\ PARAPROFESSIONAL CHARACTERISTICS \\ PREDICT RATINGS OF IMPORTANCE OR REPORTS OF SKILL INSTRUCTION?}

Only two variables-familiarity with the broader self-determination construct and opportunities to 
participate in professional development activities related to self-determination-were statistically significant predictors of importance ratings. Familiarity accounted for $12 \%$ of variance in importance, $F(1,184)=25.88, p<.0001$, and professional development addressing self-determination skills accounted for an additional 3\% of the variance, $F(1,184)=7.10, p=.008$. Paraprofessionals with greater familiarity or more prior opportunities to participate in professional development addressing self-determined behaviors placed greater importance on self-determination skills for the students with whom they worked.

When predicting the frequency with which self-determination skills were taught, the same two variables (i.e., familiarity with the construct and opportunities to participate in professional development activities related to self-determination) entered the second model. Familiarity accounted for $13 \%$ of variance in the frequency of instruction, $F(1,184)=18.18, p<.0001$, and professional development addressing self-determination skills accounted for an additional 3\% of the variance, $F(1,184)=7.71, p=.006$. Again, paraprofessionals with greater familiarity or more prior opportunities to participate in professional development addressing self-determined behaviors reported spending more time teaching selfdetermined behaviors to the students with whom they worked. The other variables (i.e., school level, work setting, gender, years of experience, educational attainment) were not predictive of either the importance or instructional frequency ratings.

\section{HOW FAMILIAR ARE}

PARAPROFESSIONALS WITH THE

BROADER SELF-DETERMINATION

CONSTRUCT?

Paraprofessionals reported that they had some familiarity with the concept of self-determined behavior for students with disabilities $(M=1.99$, $S D=0.63$ ), with even lower levels of access to professional development opportunities pertaining to self-determined behaviors $(M=1.74, S D=$ 0.68 ). Results revealed a statistically significant, but low correlation between these two items ( $r=$ $.23, p=.007$ ), indicating a limited relation between familiarity and professional development.
Yet, both variables were predictive of the importance of the construct and instructional time devoted to teaching self-determination skills.

\section{DISCUSSION}

Paraprofessionals have assumed an increasingly prominent place in the education of students with disabilities in public schools in the United States. Although their proper roles within the classroom are still being discussed and debated (Giangreco, Broer, \& Suter, 2011; McGrath, Johns, \& Mathur, 2010), it is instructive to determine how these staff view and are involved in addressing those instructional domains that have been previously prioritized by teachers. This descriptive study provides an initial glimpse into the domain of self-determination and extends the knowledge base in the following ways.

First, the vast majority of paraprofessionals considered each of the seven self-determination skills to represent important learning goals for the students with whom they worked most closely. As school staff members who often spend considerable time working with and getting to know students with disabilities, their insights lend additional weight to recent calls to expand the opportunities students receive in school to become more independent and self-determining (Cobb et al., 2009; Wehmeyer, Palmer, Shogren, Williams, \& Soukup, in press). Although we did not ask paraprofessionals whether they primarily provided instructional support in one-to-one or smallgroup contexts, we anticipated that they might view promoting self-determined behavior as incongruous with the provision of paraprofessional support. Anecdotally, in our own work with schools, we have heard paraprofessionals suggest that promoting student self-determination could render their jobs no longer necessary, an issue they typically frame as a concern. However, the views of paraprofessionals in this survey study largely echoed the instructional priorities of both special and general educators reported in previous studies (Carter et al., 2008; Cho et al., 2011; Stang et al., 2009; Wehmeyer et al., 2000). The degree of support that paraprofessionals reported is somewhat encouraging, as their alignment with what teachers regard as important could presum- 
ably influence the extent to which students are encouraged to develop and/or practice these seven self-determination skills. Indeed, we documented strong positive correlations between ratings of skill importance and skill instruction.

Given the absence of accompanying qualitative interviews, we do not know the primary reasons these paraprofessionals affirm the overall importance of self-determination as an instructional domain or why some individual skill areas (e.g., problem-solving skills, choice-making skills) were perceived to be more important than others (e.g., self-management and self-regulation). Do these reflect the specific priorities articulated by their supervising teachers? Do they reflect the actual educational goals of the students with whom these paraprofessionals worked-either written in individualized education programs or reflected in grade-level standards? Or are the views of paraprofessionals shaped by other factors? Additional research is needed to address these questions and elucidate how decisions about the instructional supports that paraprofessionals provide are ultimately made.

Second, the extent to which paraprofessionals reported teaching each of the seven self-determination skills to the students with whom they worked was fairly moderate, with average ratings all slightly above the midpoint of the scale. In other words, the majority of paraprofessionals reported sometimes or often being involved in teaching each skill. Although some skills (e.g., problem-solving skills, choice-making skills) were reported to have been addressed somewhat more often than others (e.g., goal setting and attainment; decision making), paraprofessionals' reports provide further evidence that self-determination instruction is gaining a noticeable place in the education of students with high-incidence disabilities (Eisenman, 2007; Konrad, Fowler, Walker, Test, \& Wood, 2007). Unfortunately, we do not know the specific forms that this instruction took (e.g., curricular programs, discrete instruction, encouraging skill use) or the extent to which highly qualified teachers directed and supervised these efforts. As noted at the outset of this article, although paraprofessionals can provide instrumental instructional supports under the auspices of a general or special educator, they "should not be providing planned direct instruction, or intro- ducing to students new skills, concepts, or academic content" (U.S. Department of Education 2004, p. 1). Thus, the degree to which these findings are encouraging-or cause for furrther concern-may lie in whether paraprofessionals ultimately assumed support roles that extended beyond those outlined in federal, state, and district policies.

As with all instruction, however, it is not merely the frequency with which instruction occurs that is important, but also the quality and impact of that instruction. We encourage future researchers to extend this line of inquiry to examine the quality of instruction in self-determination skills in relation to student outcomes 'e.g., academic, behavioral, social, etc.). It is not clear from our study how much guidance paraprofessionals actually received when providing said instruction, nor did we evaluate the quality and effectiveness of their instructional practices. Moreover, there are very few published inter:vention studies in which paraprofessionals have served as interventionists (e.g., Durlak, Rose, \& Bursuck, 1994; Lane, Fletcher, Carter, Dejud, \& Delorenzo, 2007; Martin et al., 2003). Thus, the field still has little empirical guidance for how best to train and supervise paraprofessionals to support the development of self-determination among the students with whom they work. Additional research is needed that articulates how paraprofessionals might play an effective but appropriately guided role in fostering greater selfdetermination among the students.

\section{It is not merely the frequency with which instruction occurs that is important, but also the quality and impact of that instruction.}

Third, we found higher ratings of importance were strongly and positively associated with reported instructional frequency across all seven self-determination component skills. Although the direction of this relation remains unclear, a number of intriguing possibilities exist. It may be that the importance paraprofessionals place on a domain impacts what they actually address with students, a finding that would be particularly 
problematic. Conversely, it may be that providing instructional support related to these skills shapes their perceptions of skill importance. Other factors-such as training, prior experiences, or the general curriculum-could play an influential role. The intersection of personal views and actual practices among paraprofessionals represents a compelling and much needed line of research. Further, the reasons that paraprofessionals were less involved in teaching particular self-determination skills-despite highly valuing those skills-should also be explored.

Fourth, we found that personal demographics (e.g., gender, highest degree) and work contexts (e.g., classroom serting, grade level) were not predictive of the degree to which paraprofessionals prioritized or provided instruction across the seven component elements of self-determination. Given the relatively recent emphasis given to selfdetermination in the field of special education (Field, Martin, Miller, Ward, \& Wehmeyer, 1998), we were somewhat surprised that number of years of experience was not more strongly associated with paraprofessionals' ratings. We were encouraged at the consistency of the frequency and importance ratings, regardless of years of experience. Similarly, we anticipated that paraprofessionals working at the secondary level would focus more attention on these skills than those working with elementary students. Instead, we found that prior training and familiarity with selfdetermination were the most prominent predictors of the importance ratings or instructional frequency. This bodes well, as both represent malleable factors that could be addressed during initial or ongoing training opportunities provided to paraprofessionals.

\section{LIMITATIONS AND FUTURE RESEARCH}

This study focused narrowly on the domain of self-determination operationalized as seven component skills. We did not query paraprofessionals about other aspects of self-determination or related skills that may be associated with self-determination, including social skills (Nota, Ferrari, Soresi, \& Wehmeyer, 2007; Pierson, Carter, Lane, \& Glaeser, 2008) and transition-related skills (Shogren et al., 2007). We also relied upon selfreport of level of disability to categorize those paraprofessionals who worked with students with high-incidence (vs. low-incidence) disabilities and did not ask with how many different students these staff worked. Demographic information provided by paraprofessionals in this study suggests that many of these paraprofessionals worked with students having a range of disability labels and support needs. Thus, the degree to which their perceptions can be pinpointed to particular students is not possible to discern in this sample.

In addition, the types of prior training and professional development these paraprofessionals received is important to explore in further depth, as this study provides few details about how paraprofessionals were trained. The limited availability of training opportunities for these staff is a recurring concern in the literature (Giangreco, Suter, \& Doyle, 2010; Liston, Nevin, \& Malian, 2009), despite IDEA's (2004) emphasis that paraprofessionals should be "appropriately trained and supervised” (20 U.S.C. $\$ 1412[a][15][B])$.

Still unaddressed is the question of why paraprofessionals consider some skills to be more important than others and how such an understanding might impact the extent or quality with which they provide or support instruction in or opportunities to practice particular skills. Qualitative studies to explore or probe these issues in greater depth are warranted. Also, although schools were randomly selected and all paraprofessionals were invited to participate, we were not able to evaluate whether any differences existed berween staff who participated and those who did not choose to participate in our study. In addition, because our sample was drawn from only three large service regions, additional research is needed to determine the extent to which these findings are consistent in other locales. Because districts may differ widely in their policies and practices regarding implementation of paraprofessional supports (Giangreco et al., 2009), it is important to explore whether and how the perspectives of paraprofessionals are shaped by school- and district-level factors.

\section{CONCLUSION}

Despite these limitations, we view this study as an important first step in examining paraprofes- 
sionals' perspectives on promoting self-determination for students with high-incidence disabilities. Given the importance of improving self-determined behaviors among these students to enhance outcomes within and beyond the school setting, we contend that additional inquiry is needed to further address the questions raised by this study. For now, we are encouraged by the high levels of importance paraprofessionals attributed to each of the seven component elements of self-determination. We hope that future efforts will focus on the ways in which paraprofessionals might effectively and appropriately support the self-determination development of the students with whom they work.

\section{REFERENCES}

Borthwick-Duffy, S. A., Lane, K. L., \& Widaman, K. F. (1997). Measuring problem behaviors in children with mental retardation: Dimensions and predictors. Research in Developmental Disabilities, 18, 415-433. doi:10.1016/S0891-4222(97)00020-6

Carter, E. W., Lane, K. L., Crnobori, M., Bruhn, A. L., \& Oakes, W. P. (2011). Self-determination interventions for students with and at risk for emotional and behavioral disorders: Mapping the knowledge base. Behavioral Disorders, 36, 100-116.

Carter, E. W., Lane, K. L., Pierson, M. R., \& Glaeser, B. (2006). Self-determination skills and opportunities of transition-age youth with emotional disturbance and learning disabilities. Excepticnal Children, 72, 333-346. Carter, E. W., Lane, K. L., Pierson, M. R., \& Stang, K. K. (2008). Promoting self-determination for transitionage youth: Views of high school general and special educators. Exceptional Children, 75, 55-70.

Carter, E. W., Lane, K. L., \& Sisco, L. G. (2011). Paraprofessional perspectives on promoting self-determination among elementary and secondary students with severe disabilities. Research and Practice for Persons with Severe Disabilities, 36, 1-10.

Carter, E. W., O’Rourke, L., Sisco, L. G., \& Pelsue, D. (2009). Knowledge, responsibilities, and training needs of paraprofessionals in elementary and secondary schools. Remedial and Special Education, 6, 344-359. doi: 10.1177/0741932508324399

Carter, E. W. Trainor, A. A., Owens, L., Swedeen, B., \& Sun, Y. (2010). Self-determination prospects of youth with high-incidence disabilities: Divergent perspectives and related factors. Journal of Emotional and
Behavioral Disorders, 18, 67-81. doi:10.1177 11063426609332605

Cho, H., Wehmeyer, M., \& Kingston, N. (2011). Elementary teachers' knowledge and use of interventions and barriers to promoting self-determination. The Journal of Special Education, 45, 149-156. doi: 10.1177/0022466910362588

Cobb, B., Lehmann, J., Newman-Gonchar, R., \&c Alwell, M. (2009). Self-determination for students with disabilities. Career Development for Exceptional Inclividuals, 32, 108-114. doi:10.1177/0885728809336654

Council for Exceptional Children. (2009). What every special educator must know: Ethics, standards, and guidelines (6th ed.). Arlington, VA: Author.

Durlak, C. M., Rose, E., \& Bursuck, W. D. (1!94). Preparing high school students with learning disabilities for the transition to postsecondary education: Teaching the skills of self-determination. Journal of Learning Disabilities, 27, 51-59. doi:10.1177 1002221949402700108

Eisenman, L. T. (2007). Self-determination inte::ventions: Building a foundation for school completion. Remedial and Special Education, 28, 2-8. doi:10.1177 107419325070280010101

Field, S., \& Hoffman, A. (2002). Preparing youth to exercise self-determination: Quality indicators of school environments that promote the acquisition of kriowledge, skills, and beliefs related to self-determination. Journal of Disability Policy Studies, 13, 113-118. doi: 10.1177/10442073020130020701

Field, S., Martin, J. E., Miller, R., Ward, M. J, \& Wehmeyer, M. L. (1998). Self-determination for persons with disabilities: A position statement of the Division on Career Development and Transition. Career Development for Exceptional Individuals, 21, 113-128. doi: $10.1177 / 088572889802100202$

Fisher, M., \& Pleasants, S. L. (in press). Roles, responsibilitics, and concerns of paraeducators: Fịndings from a statewide survey. Remedial and Special Education. doi: 10.1177/0741932510397762

Giangreco, M. F. (2010). Utilization of teacher assistants in inclusive schools: Is it the kind of help that helping is all about? European Journal of Special Needs Education, 25, 341-345. doi:10.1080/08856257 .2010 .513537$.

Giangreco, M. F., \& Broer, S. M. (2005). Questionable utilization of paraprofessionals in inclusive schools: Are we addressing symptoms or causes? Focus on Autism and Other Developmental Disabilities, 20, 10-26. doị: $10.1177 / 10883576050200010201$ 
Giangreco, M. F., Broer, S. M., \& Suter, J. C. (2011). Guidelines for selecting alternatives to overreliance on paraprofessionals: Field-testing in inclusion-oriented schools. Remedial and Special Education, 32, 22-38. doi:10.1177/0741932509355951

Giangreco, M. F., Hurley, S. M., \& Suter, J. C. (2009). Special education personnel utilization and general class placement of students with disabilities: Ranges and ratios. Intellectual and Developmental Disabilities, 47, 53-56. doi:10.1352/2009.47.53-56

Giangreco, M. F., Suter, J. C., \& Doyle, M. B. (2010). Paraprofessionals in inclusive schools: A review of recent research. Journal of Educational and Psychological Consultation, 20, 41-57. doi:10.1080 /10474410903535356

Giangreco, M. F., Yuan, S., McKenzie, B., Cameron, P., \& Fialka, J. (2005). "Be careful what you wish for ....": Five reasons to be concerned about the assignment of individual paraprofessionals. TEACHING Exceptional Children, 37(5), 28-34.

Individuals With Disabilities Education Act, 20 U.S.C. $\$ 1400$ et seq. (2004).

Keigher, A., \& Gruber, K. (2009). Characteristics of public, private, and Bureau of Indian Education elementary and secondary schools in the United States: Results from the 2007-2008 schools staffing survey (NCES 2009322). Washington DC: U.S. Department of Education National Center for Education Statistics, Institute of Education Sciences. Retrieved from http://nces.ed.gov /pubs2009/2009322.pdf

Kleinbaum, D. G., Kupper, L. L., Muller, K. E., \& Nizam, A. (1998). Applied regression analysis and other multivariable methods (3rd ed.). Pacific Grove, CA: Duxbury Press.

Konrad, M., Fowler, C. H., Walker, A. R., Test, D. W., \& Wood, W. M. (2007). Effects of self-determination interventions on the academic skills of students with learning disabilities. Learning Disability Quarterly, 30, 89-113.

Konrad, M., Walker, A. R., Fowler, C. H., Test, D. W., \& Wood, W. M. (2008). A model for aligning self-determination and general curriculum standards. TEACHING Exceptional Children, 40(3), 53-64.

Landmark, L. J., Ju, S., \& Zhang, D. (2010). Substantiated best practices in transition: Fifteen years later. Career Development for Exceptional Individuals, 33, 165-176. doi:10.1177/0885728810376410

Lane, K. L., Fletcher, T., Carter, E., W, Dejud, C., \& Delorenzo, J. (2007). Paraprofessional-led phonological awareness training with youngsters at-risk for reading and behavioral concerns. Remedial and Special
Education, 28, 266-276. doi:10.1177/074193250702 80050201

Liston, A. G., Nevin, A., \& Malian, I. (2009). What do paraeducators in inclusive classrooms say about their work? Analysis of national survey data and follow-up interviews in California. TEACHING Exceptional Children Plus, 5(5), Article 1.

Martin, J. E., Mithaug, D. E., Cox, P., Peterson, L. Y., Van Dycke, J. L., \& Cash, M. E. (2003). Increasing self-determination: Teaching students to plan, work, evaluate, and adjust. Exceptional Children, 69, $431-447$.

Mason, C., Field, S., \& Sawilowsky, S. (2004). Implementation of self-determination activities and student participation in IEPs. Exceptional Children, 70, 441-451.

McGrath, M. Z., Johns, B. H., \& Mathur, S. R. (2010). Empowered or overpowered? Strategies for working effectively with paraprofessionals. Beyond $B e$ havior, 19(2), 2-6.

Minondo, S., Meyer, L. H., \& Xin, J. F. (2001). The role and responsibilities of teaching assistants in inclusive education: What's appropriate. The Journal of the Association for Persons with Severe Handicaps, 26, 114-119.

National Alliance for Secondary Education and Transition. (2005). National standards and quality indicators: Transition toolkit for systems improvement. Minneapolis, MN: University of Minnesota, National Center on Secondary Education and Transition.

No Child Left Behind Act of 2001, 20 U.S.C. $70 \$$ 6301 et seq. (2002)

Nota, L., Ferrari, L., Soresi, S., \& Wehmeyer, M. L. (2007). Self-determination, social abilities, and the quality of life of people with intellectual disabilities. Journal of Intellectual Disability Research, 51, 850-865. doi:10.1111/j.1365-2788.2006.00939.x

Pierson, M. R., Carter, E. W., Lane, K. L., \& Glaeser, B. (2008). Factors influencing the self-determination of transition-age youth with high incidence disabilities. Career Development for Exceptional Individuals, 31, 115-125. doi:10.1177/0885728808317659

Shogren, K. A., Wehmeyer, M. L., Palmer, S. B., Soukup, J. H., Little, T. D., Garner, N., \& Lawrence, $M$. (2007). Examining individual and ecological predictors of the self-determination of students with disabilities. Exceptional Children, 73, 488-509.

Stang, K. K., Carter, E. W., Lane, K. L., \& Pierson, M. R. (2009). Perspectives of general and special educators on fostering self-determination in elementary and mid- 
dle schools. The Journal of Special Education, 43, 94-106. doi:10.1177/0022466907313452

Study of Personncl Needs in Special Education. (2002). The role of paraprofessionals in special education. Rockville, MD: Westat.

Test, D. W., Fowler, C. H., Brewer, D. M., \& Wood, W. M. (2005). A content and methodological review of self-advocacy intervention studies. Exceptional Children, $72,101-125$.

Test, D. W., Mazzorti, V. L., Mustian, A. L., Fowler, C. H., Kortering, L, \& Kohler, P. (2009). Evidence-based secondary transition predictors for improving postschool outcomes for students with disabilities. Career Development for Exceptional Individuals, 32, 160-181. doi: $10.1177 / 0885728809346960$

U.S. Department of Education. (2004, March). Title I paraprofessionals: Non-regulatory guidance. Washington, DC: Author. Retrieved from http://www2.ed.gov /policy/elsec/guid/paraguidance.pdf

Wehmeyer, M. L. (1999). A functional model of selfdetermination: Describing development and implementing instruction. Focus on Autism and Other Developmental Disabilities, 14, 53-61. doi:10.1177 $/ 108835769901400107$

Wehmeyer, M. L., Agran, M., \& Hughes, C. (2000). A national survey of teachers' promotion of self-determination and student-directed learning. The Journal of Special Education, 34, 58-68. doi:10.1177 1002246690003400201

Wehmeyer, M. L., \& Field, S. I. (2007). Self-determination: Instructional and assessment strategies. Thousand Oaks, CA: Corwin Press.

Wehmeyer, M. L., Field, S. I., Doren, B., Jones, B., \& Mason, C. (2004). Self-determination and student involvement in standards-based reform. Exceptional Children, 70, 413-425.

Wehmeyer, M. L., \& Palmer, S. B. (2003). Adult outcomes for students with cognitive disabilities three years after high school: The impact of self-determination. Education and Training in Developmental Disabilities, 38, 131-144.

Wehmeyer, M. L., Palmer, S. B., Lee, Y., WilliamsDiehm, K., \& Shogren, K. (2011). A randomized-trial evaluation of the effects of Whose Future is it Anyway? on self-determination. Career Development for Exceptional Individuals, 34, 45-56. doi:10.1177/088572 8810383559
Wehmeyer, M. L., Palmer, S. B., Shogren, K., Williams, K., \& Soukup, J. H. (in press). Establishing a causal relationship between interventions to promote self-determination and enhanced student self-dctermination. The Journal of Special Education, doi: $10.1177 / 0022466910392377$

Wisconsin Department of Public Instruction. 2010, August). Information update. Retrieved from http:// www.dpi.state.wi.us/sped/pdf/bul10-05.pdf

Zhang, D., Wehmeyer, M. L., \& Chen, L. (2005). Parent and teacher engagement in fostering the self-determination of students with disabilities: A comparison between the United States and the Republic of China. Remedial and Special Education, 26, 55-64. doi:10 $.1177 / 07419325050260010701$

\section{ABOUT THE AUTHORS}

kathleen lynNe lane (Tennessee (CEC), Professor, School of Education, The University of North Carolina at Chapel Hill; and ERık w. carter (Tennessee CEC), Associate Professor, Department of Special Education, Peabody College, Vanderbilt University, Nashville, Tennessee. LYNN sisco, Doctoral Student, Schciol of Social Work, University of Wisconsin-Madison.

This research was supported in part by a grant from the Centers for Medicare and Medicaid Services, Medicaid Infrastructure Grant to the Wisconsin Department of Health Services (CFDA No. 93.768).

This article is drawn from a larger study that also included paraprofessionals working primarily with students with low-incidence disabilities (Carter, Lane, $\&$ Sisco, 2011).

Address correspondence concerning this article to Kathleen Lynne Lane, School of Education, 201-E Peabody Hall, Campus Box 3500, University of North Carolina at Chapel Hill, Chapel Hill, NC 27599-3500 (e-mail: Kathleen.Lane@unc.edu).

Manuscript received August 2010; accepted March 2011. 
Copyright of Exceptional Children is the property of Council for Exceptional Children and its content may not be copied or emailed to multiple sites or posted to a listserv without the copyright holder's express written permission. However, users may print, download, or email articles for individual use. 